\title{
New evidences for C-reactive protein (CRP) deposits in the arterial intima as a cardiovascular risk factor
}

\author{
Fabrizio Montecucco \\ François Mach \\ Division of Cardiology, Foundation for \\ Medical Research, University Hospital, \\ Geneva, Switzerland
}

\begin{abstract}
Inflammatory processes are orchestrated by several soluble molecules, which interact with cell populations involved. Cytokines, chemokines, acute-phase reactants, and hormones are crucial in the evolution of several inflammatory disorders, such as atherosclerosis. Several evidences suggest that C-reactive protein (CRP) started to be considered as a cardiovascular risk factor, since CRP directly induces atheroslerosis development. The recent demonstration of CRP production not only by the liver, but also within atherosclerotic plaques by activated vascular cells, also suggests a possible dual role, as both a systemic and tissue agent. Although more studies are needed, some therapeutic approaches to reduce CRP levels have been performed with encouraging results. However, given the strong limitations represented by its low specificity and still accordingly with the American Heart Association, there is no need for high sensitivity CRP screening of the entire adult population as a public-health measure. The measure of serum CRP might be useful only for patients who are considered at intermediate risk.
\end{abstract}

Keywords: atherosclerosis, inflammation, plaque, cardiovascular risk, C-reactive protein

\section{Introduction}

Increasing evidence suggests a prominent role for inflammatory processes in the pathogenesis of atherosclerosis (Hansson et al 2002; Hansson and Libby 2006). Inflammatory cells and soluble mediators are key components of the atherosclerotic plaques in the different steps of lesion evolution (Worthley et al 2001; Root and Cobb 2004; Carter 2005). Therefore, although the causal factors of atherosclerosis remain unknown, inflammation represents the main field of investigations to identify new circulating biomarkers, capable of predicting plaque rupture and the consequent dramatic ischemic events, such as myocardial infarction or stroke. Several inflammatory agents, such as white blood cell count (Danesh et al 1998), cytokines (Ridker et al 2000b), chemokines (Aukrust et al 2001), and soluble adhesion molecules (Johnson et al 1997), have been studied without showing a sufficient specificity in predicting acute cardiovascular events. The low specificity compared with the high cost of the tests represents one of strong limitation for their clinical use. Also further investigations are required to better understand the role of inflammatory soluble mediators as cardiovascular risk markers or factors (Biomarkers Definitions Working Group 2001). In this context, C-reactive protein (CRP) has to be considered as the pivotal candidate to better characterize the cardiovascular risk. In fact, emerging evidence suggests that CRP is a pro-atherosclerotic factor with a causal role in atherogenesis. Furthermore, the recent demonstration of a double activity (in the blood stream and within arterial intima) supports CRP as both a predictor of cardiovascular risk and a possible therapeutic target for cardiovascular disease prevention (Koenig 2005). The present review provides an overview of the new 
evidences supporting the role of CRP in atherosclerotic inflammatory processes.

\section{Biological properties of CRP}

CRP is a member of the pentraxin family of innate immune response proteins. It was first described in 1930 by Tillet and Francis in the sera of patients suffering of pneumonia (Tillet and Francis 1930). The so called "fraction-C" precipitated when put in contact the C-polysaccharide of Streptococcus pneumoniae. The fraction-C, actually named CRP, is a nonglycosylated protein, composed by five 23-kd subunits noncovalently associated and arranged symmetrically around a central pore (Thompson et al 1999). Furthermore, the half-life of CRP is about 19 hours and this does not change in healthy conditions or disease. For these reasons, elevated circulating levels of CRP in inflammatory states are secondary to an increase of CRP production (Jialal et al 2004). In healthy subjects, the CRP baseline concentration in the plasma is about $0.8 \mathrm{mg} / \mathrm{l}$ (Ford et al 2003a), and is in part genetically regulated (Tall 2004). Single nucleotide polymorphisms (SNPs) in both CRP gene and in a number of other genes regulating CRP secretion have been found associated with CRP baseline levels in humans (Eklund et al 2003; Chasman et al 2006; Lakka et al 2006; Sykora et al 2006; Jakimiuk et al 2007; Osawa et al 2007; Shin et al 2007; Tang et al 2007; Walston et al 2007; Wong et al 2007; Zhang et al 2007b). Although still controversial, the modulation of CRP levels by other gene products might be considered as a very promising field for future investigations. Further studies of larger samples are warranted to assess the determination of CRP levels by polymorphisms in other genes. In humans, the gene encoding CRP is mapped to chromosome 1 (1q23-24) and consists of 2 exons. SNPs in the CRP gene promoter have been found associated to differences in baseline serum CRP levels (Kovacs et al 2005; Szalai et al 2005). In addition, also polymorphic sequences in other portions of CRP gene have been identified (Cao and Hegele 2000; Szalai et al 2002; Russell et al 2004; Miller et al 2005) and associated with immune-mediated diseases or interindividual variations of baseline CRP production (Miller et al 2005; Kathiresan et al 2006). A recent study by Kathiresan and co-workers (2006) showed that common triallelic CRP SNP contributed modestly to CRP baseline levels in Framingham Heart Study participants. Clinical characteristics resulted as the most important variables implicated in variations of CRP (Kathiresan et al 2006). This has been confirmed by another study showing that the most common causes of CRP deficiency are represented by liver failure or therapies affecting the acute-phase stimulus (Vermeire et al 2004). Therefore, SNPs in other genes and clinical conditions appear as implicated in the regulation of CRP baseline levels rather than SNPs in CRP gene. On the other hand, CRP secretion is increased by infections (bacterial, fungal, mycobacterial, or severe viral) (Du Clos and Mold 2004), tissue necrosis (Dominguez-Munoz and Malfertheiner 1993), trauma (Du Clos 2000), neoplasia (Mahmoud and Rivera 2002), and other inflammatory disorders, including atherosclerosis (Lagrand et al 1999). In all of these clinical syndromes, serum levels of CRP are increased by liver production in response to a variety of inflammatory cytokines, such as IL-6, tumor necrosis factor (TNF)-alpha (Bastard et al 2006) and IL-1 (Vermeire et al 2004). In the last decades, it was assumed that exclusively hepatocytes were capable of producing CRP (Sun et al 2005). However, the detection of CRP deposits in other tissues (Sun et al 2005) suggested that other cell types should be capable of producing CRP. Different cell populations, localized both in the atherosclerotic plaque or other tissues, are capable of expressing (Kolb-Bachofen et al 1995; Dong and Wright 1996; Singh et al 2007) or secreting (Kuta and Baum 1986; Ikuta et al 1986; Calabró et al 2003) CRP. Although the quantities of CRP production between liver and other tissues are not comparable, a recent work showed that atherosclerotic plaques are capable of releasing CRP in the blood stream and modifying local blood CRP levels (Inoue et al 2005). Therefore, this evidence strongly supports CRP not only as an endocrine (systemic) inflammatory marker, but also as a paracrine (local) pro-atherosclerotic factor.

\section{Is CRP a cardiovascular risk marker or factor?}

Numerous prospective epidemiologic studies showed that in healthy subjects serum CRP predicts myocardial infarction mortality (Ridker et al 2000a, 2002; Boekholdt et al 2006), peripheral vascular disease (Ridker et al 1998b, 2001), congestive heart failure (Cesar et al 2003; Vasan et al 2003), stroke (Ridker et al 1997, 1998a; Gussekloo et al 2000) and arrhythmias, including sudden cardiac death (Albert et al 2002). A meta-analysis of 14 prospective long-term studies showed that after correction for age, smoking, cardiovascular risk factors, and indicators of socioeconomic status, CRP was strongly related to coronary heart disease (Danesh et al 2000). In these studies, CRP levels were not influenced by Helicobacter pylori, HIV seropositivity, or Chlamydia pneumoniae immunoglobulin (IgG) titres. Therefore, in this paper these data appeared to support CRP as a potent cardiovascular risk marker, unrelated to other chronic 
inflammatory states, such as chronic infections. However, other studies showed that CRP serum levels are increased in autoimmune diseases and infections (Mendall et al 2000; Roivainen et al 2000; Park et al 2002). A more recent clinical study by Danesh and co-workers (2004) strongly reduced the impact of CRP as a predictor of cardiovascular events. The authors, after a meta-analysis of twenty-two prospective studies, concluded that CRP is a "relatively moderate" predictor of coronary heart disease. On the basis of these different results, CRP specificity for cardiovascular diseases appears to be low and recommendations regarding its clinical use for predicting acute cardiovascular events require validation. On the other hand, the association between chronic inflammatory diseases (with high CRP levels) and increased risk of coronary heart diseases (Roivainen et al 2000; Park et al 2002; Ridker et al 2001; Lowe et al 2001) suggests that CRP might be considered as a cardiovascular risk factor rather than marker. To summarize, high CRP serum levels are induced in several inflammatory conditions and are not specific for atherosclerosis. However, once established at high levels, CRP increases the cardiovascular risk. On the basis of these still controversial evidences, the American Heart Association and Centers for Disease Control and Prevention recommended to use CRP as a risk marker for cardiovascular diseases in individual with a Framingham risk score between $10 \%$ and $20 \%$ (Pearson et al 2003). This subgroup of patients may benefit from high-sensitivity (hs)-CRP testing, mainly because physicians are often undecided about the treatment for a patient who is considered at intermediate risk. In this case, an hs-CRP test might tip the scale to help a physician deciding on moderate or more intensive prevention treatment. However, the use of hs-CRP is also limited by the presence of other concomitant inflammatory diseases. Thus, the answer to the question "is there any role for its routine measurement?" is still "it depends" (Ben-Yehuda 2007). Further investigations are needed to better characterize CRP as a marker for improving cardiovascular risk stratification.

\section{CRP is a potential independent cardiovascular risk factor}

In order to investigate the role of CRP in the immune response, several papers previously indicated that it is necessary to exclude possible pro-inflammatory artefacts due to the contamination of CRP commercial preparations. Contaminants (mainly sodium azide, LPS or IgG fragments) have been shown to induce significant pro-inflammatory effects on several cell types (Han et al 2004; Van den Berg et al 2004; Taylor et al 2005; Pepys et al 2005; Nerurkar et al 2005). Although these limitations, several studies showed that CRP is capable of activating complement and binding lipoproteins (Rowe et al 1984) or lysophospholipids (Mori et al 1991), also generated after myocardial infarction (Van der Vusse et al 1994). This evidence suggested that CRP could be not only an innocent bystander marker, but also an active factor in immune response underlying atherosclerotic processes. A direct contribution of CRP to atherosclerosis has been suggested by both in vitro and in vivo experiences on different cell populations, such as endothelial cells, leukocytes and smooth muscle cells. CRP increases adhesion molecules expression, such as ICAM, VCAM, E-selectin in human umbilical vein endothelial cells (ECs) (Pasceri et al 2000). Furthermore, CRP reduces both protein and mRNA for endothelial nitric oxide synthase (eNOS) in human coronary artery endothelial cells (HAEC) (Venugopal et al 2002) and human venous ECs (Verma et al 2002b). On the contrary, inducible nitric oxide synthase (iNOS) activity was increased by CRP. The increase of adhesion molecules expression and iNOS activity and the reduction of eNOS clearly support the crucial role of CRP on endothelium activation. Further evidences also support CRP as endothelial dysfunction causal factor (Verma et al 2002a; Venugopal et al 2003; Devaraj et al 2003). Also monocytemacrophages are triggered by CRP for pro-atherosclerotic functions. High levels of CRP induce monocyte chemotaxis and differentiation (Torzewski et al 2000; Zhang et al 2006), cytokine production (Ballou and Lozanski 1992), integrin $\mathrm{CD} 11 \mathrm{~b}$ and chemokine receptor upregulation (Woollard et al 2002; Han et al 2004), monocyte-platelets aggregation (Danenberg et al 2007) and oxidized low density lipoprotein (LDL) uptake (Chang et al 2002) through the binding to Fc- $\gamma$ receptor I (CD64) and II (CD32). These studies suggest a pro-atherosclerotic role of CRP mainly in early phases of atherogenesis. However, other researchers recently showed that CRP could be involved also in later stages of atherosclerosis, by inducing both matrix metalloproteinase (MMP)-1 and MMP-9 expression and collagenase activity in human monocyte-macrophages (Williams et al 2004; Nabata et al 2007). The function of neutrophils is also modulated by CRP. Neutrophil $N$-formyl-methionyl-leucyl-phenylalanine (fMLP)-induced chemotaxis and superoxide production were both inhibited by CRP (Zhong et al 1998; Mortensen and Zhong 2000). CRP also modulates smooth muscle cell pro-atherosclerotic functions. CRP upregulates angiotensin type-1 receptor $\left(\mathrm{AT}_{1} \mathrm{R}\right)$ on smooth muscle cells and increases angiotensin II-induced smooth muscle cells migration and proliferation (Wang et al 2003). In vivo studies showed a 
possible direct role for CRP as a pro-atherosclerotic factor. The low importance of acute-phase proteins in animals represents a strong limitation in developing in vivo models. Mouse CRP is a trace protein with a concentration which not exceeded $2 \mathrm{mg} / \mathrm{L}$ even after an inflammatory stimulus (Pepys and Hirschfield 2003). Recently, an important study showed that transgenic apolipoprotein $\mathrm{E}$ (ApoE) deficient mice, expressing high serum levels of human CRP (100 mg/L), develop an acceleration of atherosclerotic lesion formation in comparison with control 7-month-old male ApoE deficient mice (Paul et al 2004). The strong limitation of this study was represented by the high levels of CRP in these mice, not comparable with CRP levels (1-10 mg/L) detected in humans with increased cardiovascular risk (Pearson et al 2003). Given the role of CRP in inflammatory processes in hypercholesterolemic rabbits (Asgary et al 2007; Zhang et al 2007a), these animals and also transgenic mice expressing rabbit CRP could represent a good in vivo model for studying CRP in atherosclerosis (Xia and Samols 1997; Jiang et al 2006). However, further investigations are needed to validate this experimental approach. Therefore, given the strong limitations due to a possible effect of contaminants of the commercial compounds and the controversies in genetic studies (human SNPs and transgenic animal models) (Miller et al 2005; Balistreri et al 2006; Eklund et al 2007; Pai et al 2008), we can consider CRP as a potential independent proatherosclerotic factor. Therefore, although further evidences are needed, a therapeutic approach to reduce vascular CRP pro-inflammatory activities could represent a possible new target to influence the development of atherosclerosis.

\section{Therapeutic strategies to reduce CRP levels}

Given the physiopathological role of CRP in atherosclerotic pro-inflammatory processes, lowering CRP serum levels and vascular CRP synthesis or deposition might bean interesting strategy to reduce cardiovascular risk. Although detection of vascular CRP deposit in vivo appears to be difficult, cardiovascular screening programs are needed to identify and treat at least patients with high concentrations of serum CRP. Behavioral or pharmacologic interventions have been proposed to reduce CRP serum levels. Weight loss and the reduction of adiposity were showed to induce favorable changes in hsCRP level (Tchernof et al 2002; Esposito et al 2003; Kopp et al 2003). Regular physical activity, beside weight loss, was shown to reduce CRP serum levels in several studies (Geffken et al 2001; Wannamethee et al 2002; Ford 2002; Abramson and Vaccarino 2002; Reuben et al 2003).
This anti-inflammatory effect was also found in subjects without cardiovascular diseases (LaMonte et al 2002; Church et al 2002). For this reason, physical activity could and should be considered as a very promising CRP lowering strategy to prevent cardiovascular diseases. On the other hand, cigarette smoking was found to increase CRP as well as other cardiovascular risk factors and markers (Bermudez et al 2002; Bazzano et al 2003). Smoking cessation could represent an interesting approach to reduce CRP serum levels, but studies focused on this aspect are needed. Concerning alcohol consumption, light alcohol intake rather than abstension or abuse is associated with lower cardiovascular mortality and lower CRP serum levels (Fuchs et al 1995; Albert et al 2003). The intake of various dietary factors, such as long-chain $\omega-3$ polyunsaturated fatty acids, retinol, vitamin $\mathrm{C}$, serum folate caroteoids and selenium was also found inversely associated to CRP serum levels (Pischon et al 2003; Ford et al 2003b). However, further studies are needed in order to identify a possible causal role for these agents in regulating CRP production. On the other hand, several pharmacolagic molecules have been showed to reduce CRP levels. Lipid-modulating medications, including 3-hydroxy3-methylglutaryl coenzyme A reductase inhibitors (statins), fibrates and niacin, have been found to influence directly, beyond lipid lowering properties, inflammatory serum factor levels (Blake and Ridker 2002; Melenovsky et al 2002; Kashyap et al 2002). Statins reduced CRP concentrations through a direct action on hepatocyte intracellular signalling pathways (Ridker et al 1999; Arnaud et al 2005). The role of LDL in statin induced CRP modulation is controversial. A recent study showed that changes in LDL correlates with changes in CRP levels (Ansell et al 2003). On the contrary, other evidence showed an independent relationship between these two factors (Ridker et al 1999). Therefore, further evidences are needed to better clarify the molecular mechanisms involved in statin-induced reduction of CRP serum levels. Both fibrates and niacin have been showed to reduced CRP serum levels and cardiovascular risk in hyperlipidemic patients (Grundy et al 2002; Després et al 2003). However, the molecular mechanism involved remains unclear. Also aspirin and other anti-platelets agent protective activity might be dependent on CRP serum levels. Reduction of cardiovascular risk induced by aspirin, clopidogrel or abciximab treatment was higher in patients with elevated CRP levels (Ridker et al 1997; Chew et al 2001; Lincoff et al 2001). However, a direct activity of these pharmacologic agents on reducing CRP serum levels is still controversial (Ikonomidis et al 1999; Feldman et al 2001; Backes et al 
2004). Finally, anti-hyperglycemic agents have been showed to reduce CRP serum levels (Staels et al 1998; Haffner et al 2002). Also in this case, the molecular mechanisms involved remain still not identified. Surprisingly, recent clinical studies showed that thiazolidinediones induce an increase of acute cardiovascular outcomes (Lipscombe et al 2007; Nissen and Wolski 2007). Given these contrasting results, further studies are needed to clarify the role of CRP in patients treated with thiazolidinediones.

\section{Conclusions}

The present review shows recent experimental evidences to support CRP as a potential cardiovascular risk factor with direct activities in cardiovascular disease. Circulating levels of CRP and vascular CRP (localized within atherosclerotic plaques) could play a dual role as an endocrine and a paracrine agent. The properties of CRP localized in arterial intima could also suggest an interesting hypothesis to clarify how in several studies CRP serum levels were not related to the cardiovascular risk. It is possible that CRP deposition within atherosclerotic plaque, rather than serum CRP levels can be involved in atherosclerotic processes (Figure 1). Although the last guidelines on cardiovascular diseases by the European Society of Cardiology do not support CRP as a marker of cardiovascular risk (Nissen and Wolski 2007; Rydén et al 2007; Mancia et al 2007), the American Heart Association (AHA/CDC) suggests that the measurement of CRP dosage might be useful only when physicians are undecided about indications of treatment for patients who are considered at intermediate cardiovascular risk. In this case, hs-CRP test might tip the scale to help a physician on their decision to introduce more intensive treatment (Ridker et al 2007). Since for cardiovascular risk stratification the determination of CRP levels between 1 and $10 \mathrm{mg} / \mathrm{L}$ is needed (Pearson et al 2003), the indicated test is hs-CRP measurement, which measures values under $10 \mathrm{mg} / \mathrm{L}$ (Libby and Ridker 2004). The AHA also suggests that there is no need for hs-CRP screening of the entire adult population as a public-health measure, mainly because we do not have enough evidence that treatment strategies based on hs-CRP levels improve survival or reduce cardiovascular complications. To clarify this finding, further prospective studied are needed (Tchernof et al 2002). Therefore, although the AHA experts identified a subgroup of patients who may benefit from hs-CRP testing, at present, for most patients the

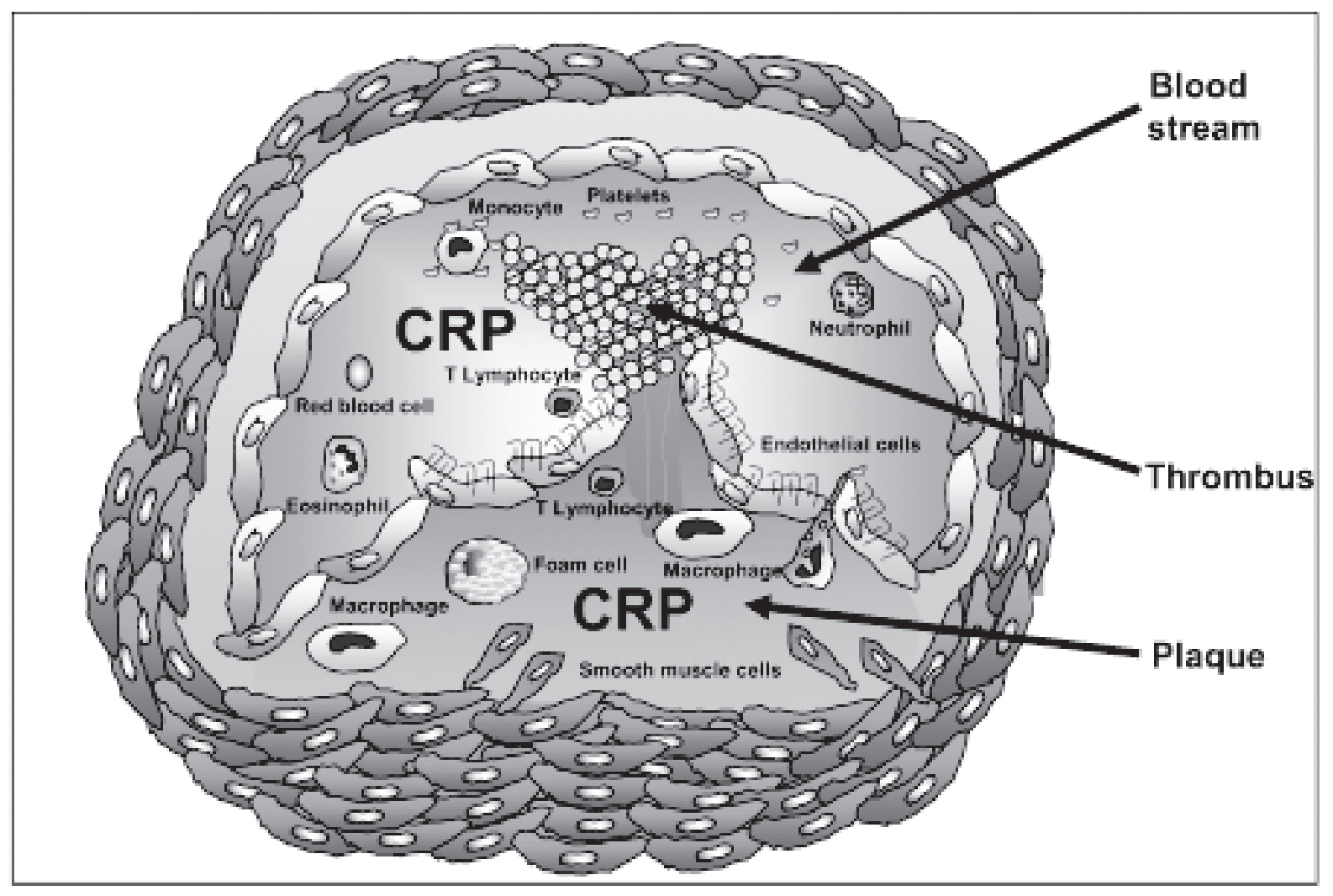

Figure I Role of C-reactive protein (CRP) in atherosclerotic processes. CRP is a cardiovascular risk factor with a possible dual pro-atherosclerotic activity as both an endocrine or paracrine molecule. Localization of CRP within unstable or ruptured plaques suggests a possible crucial role during acute atherosclerotic events. 
emphasis must remain on detection, treatment and control of the major cardiovascular risk factors indicated by The Framingham Study, with the inclusion of obesity.

\section{Acknowledgments}

This work was supported by grants from the Swiss National Science Foundation to Dr. F. Mach (\# 320080-105836). The authors belong to the European Vascular Genomics Network (http://www.evgn.org): a Network of Excellence supported by the European Community.

\section{References}

Abramson JL, Vaccarino V. 2002. Relationship between physical activity and inflammation among apparently healthy middle-aged and older US adults. Arch Intern Med, 162:1286-92.

Albert CM, Ma J, Rifai N, et al. 2002. Prospective study of C-reactive protein, homocysteine, and plasma lipid levels as predictors of sudden cardiac death. Circulation, 105:2595-9.

Albert MA, Glynn RJ, Ridker PM. 2003. Alcohol consumption and plama concentration of C-reactive protein. Circulation, 107:443-7.

Ansell BJ, Watson KE, Weiss RE, et al. 2003. hsCRP and HDL Effects Statin Trial (CHEST): rapid of effect of statin therapy on C-reactive protein and high-density lipoprotein levels. A clinical investigation. Heart Dis, 5:2-7.

Arnaud C, Burger F, Steffens S, et al. 2005. Statins reduce interleukin-6induced C-reactive protein in human hepatocytes: new evidence for direct antiinflammatory effects of statins. Arterioscler Thromb Vasc Biol, 25:1231-6.

Asgary S, Moshtaghian J, Naderi G, et al. 2007. Effects of dietary red clover on blood factors and cardiovascular fatty streak formation in hypercholesterolemic rabbits. Phytother Res, 21:768-70.

Aukrust P, Berge RK, Ueland T, et al. 2001. Interaction between chemokines and oxidative stress: possible pathogenetic role in acute coronary syndromes. J Am Coll Cardiol, 37:485-91.

Backes JM, Howard PA, Moriarty PM. 2004. Role of C-reactive protein in cardiovascular disease. Ann Pharmacother, 38:110-18.

Balistreri CR, Vasto S, Listi F, et al. 2006. Association between $+1059 \mathrm{G} / \mathrm{C}$ CRP polymorphism and acute myocardial infarction in a cohort of patients from Sicily: a pilot study. Ann N Y Acad Sci, 1067:276-81.

Ballou SP, Lozanski G. 1992. Induction of inflammatory cytokine release from cultured human monocytes by C-reactive protein. Cytokine, $4: 361-8$.

Bastard JP, Maachi M, Lagathu C, et al. 2006. Recent advances in the relationship between obesity, inflammation, and insulin resistance. Eur Cytokine Netw, 17:4-12.

Bazzano LA, He J, Muntner P, et al. 2003. Relationship between cigarette smoking and novel risk factors for cardiovascular disease in the United States. Ann Intern Med, 138:891-7.

Ben-Yehuda O. 2007. High-sensitivity C-reactive protein in every chart? The use of biomarkers in individual patients. $\mathrm{J} \mathrm{Am} \mathrm{Coll} \mathrm{Cardiol,}$ 49:2139-41

Bermudez EA, Rifai N, Buring JE, et al. 2002. Relation between markers of systemic vascular inflammation and smoking in women. Am J Cardiol, 89:1117-19.

Biomarkers Definitions Working Group. 2001. Biomarkers and surrogate endpoints: preferred definitions and conceptual framework. Clin Pharmacol Ther, 69:89-95.

Blake GJ, Ridker PM. 2002. Inflammatory bio-markers and cardiovascular risk prediction. J Intern Med, 252:283-94.

Boekholdt SM, Hack CE, Sandhu MS, et al. 2006. C-reactive protein levels and coronary artery disease incidence and mortality in apparently healthy men and women: the EPIC-Norfolk prospective population study 1993-2003. Atherosclerosis, 187:415-22.
Calabró P, Willerson JT, Yeh ET. 2003. Inflammatory cytokines stimulated C-reactive protein production by human coronary artery smooth muscle cells. Circulation, 108:1930-2.

Cao H, Hegele RA. 2000. Human C-reactive protein (CRP) 1059G/C polymorphism. J Hum Genet, 45:100-1.

Carter AM. 2005. Inflammation, thrombosis and acute coronary syndromes. Inflammation, thrombosis and acute coronary syndromes. Diab Vasc Dis Res, 2:113-21.

Cesari M, Penninx BW, Newman AB, et al. 2003. Inflammatory markers and onset of cardiovascular events: results from the Health $\mathrm{ABC}$ study. Circulation, 108:2317-22.

Chang MK, Binder CJ, Torzewski M, et al. 2002. C-reactive protein binds to both oxidized LDL and apoptotic cells through recognition of a common ligand: Phosphorylcholine of oxidized phospholipids. Proc Natl Acad Sci USA, 99:13043-8.

Chasman DI, Kozlowski P, Zee RY, et al. 2006. Qualitative and quantitive effects of APOE genetic variation on plasma C-reactive protein, LDLcholesterol, and apoE protein. Genes Immun, 7:211-19.

Chew DP, Bhatt DL, Robbins MA, et al. 2001. Effect of clopidogrel added to aspirin before percutaneous coronary intervention on the risk associated with C-reactive protein. Am J Cardiol, 88:672-4.

Church TS, Barlow CE, Earnest CP, et al. 2002. Associations between cardiorespiratory fitness and C-reactive protein in men. Arterioscler Thromb Vasc Biol, 22:1869-76.

Danenberg HD, Kantak N, Grad E, et al. 2007. C-reactive protein promotes monocyte-platelet aggregation: an additional link to the inflammatorythrombotic intricacy. Eur J Haematol, 78:246-52.

Danesh J, Collins R, Appleby P, et al. 1998. Association of fibrinogen, C-reactive protein, albumin, or leukocyte count with coronary heart disease: meta-analyses of prospective studies. JAMA, 279:1477-82.

Danesh J, Whincup P, Walker M, et al. 2000. Low grade inflammation and coronary heart disease: prospective study and updated meta-analyses. BMJ, 321:199-204.

Danesh J, Wheeler JG, Hirschfield GM, et al. 2004. C-reactive protein and other circulating markers of inflammation in the prediction of coronary heart disease. $N$ Engl J Med, 350:1387-97.

Després JP, Lemieux I, Pascot A, et al. 2003. Gemfibrozil reduces plasma C-reactive protein levels in abdominally obese men with the atherogenic dyslipidemia of the metabolic syndrome. Arterioscler Thromb Vasc Biol, 23:702-3.

Devaraj S, Xu DY, Jialal I. 2003. C-reactive protein increases plasminogen activator inhibitor-1 expression and activity in human aortic endothelial cells: implications for the metabolic syndrome and atherothrombosis. Circulation, 107:398-404.

Domínguez-Muñoz JE, Malfertheiner P. 1993. Management of severe acute pancreatitis. Gastroenterologist, 1:248-56.

Dong Q, Wright JR. 1996. Expression of C-reactive protein by alveolar macrophages. J Immunol, 156:4815-20.

Du Clos TW. 2000. Function of C-reactive protein. Ann Med, 32:274-8.

Du Clos TW, Mold C. 2004. C-reactive protein: an activator of innate immunity and a modulator of adaptive immunity. Immunol Res, 30:261-77.

Eklund C, Jahan F, Pessi T, et al. 2003. Interleukin 1B gene polymorphim is associated with baseline $\mathrm{C}$-reactive protein levels in healthy individuals. Eur Cytokine Netw, 14:168-71.

Eklund C, Kivimaki M, Islam MS, et al. 2007. C-reactive protein genetics is associated with carotid artery compliance in men in The Cardiovasculat Rik in Young Finns Study. Atherosclerosis, 196:841-8.

Esposito K, Pontillo A, Di Palo C, et al. 2003. Effect of weight loss and lifestyle changes on vascular inflammatory markers in obese women: a randomized trial. JAMA, 289:1799-804.

Feldman M, Jialal I, Devaraj S, et al. 2001. Effects of low-dose aspirin on serum C-reactive protein and thromboxane B2 concentrations: a placebo-controlled study using a highly sensitive $\mathrm{C}$-reactive protein assay. J Am Coll Cardiol, 37:2036-41.

Ford ES. 2002. Does Exercise reduce inflammation? Physical activity and C-reactive protein among U.S. adults. Epidemiology, 13:561-8. 
Ford ES, Giles WH, Myers GL, et al. 2003. C-reactive protein concentration distribution among US children and young adults: findings from the National Health and Nutrition Examination Survey, 1999-2000. Clin Chem, 49:1353-7.

Ford ES, Liu S, Mannino DM, et al. 2003. C-reactive protein concentrations of blood vitamins, carotenoids, and selenium among United States adults. Eur J Clin Nutr, 57:1157-63.

Fuchs CS, Stampfer MJ, Colditz GA, et al. 1995. Alcohol consumption and mortality among women. $N$ Engl J Med, 332:1245-50.

Geffken DF, Cushman M, Burke GL, et al. 2001. Association between physical activity and markers of inflammation in a healthy elderly population. Am J Epidemiol, 153:242-50.

Grundy SM, Vega GL, McGovern ME, et al. 2002. Efficacy, safety, and tolerability of once-daily niacin for the treatment of dyslipidemia associated with type 2 diabetes: results of the assessment of diabetes control and evaluation of the efficacy of niaspan trial. Arch Intern Med, 162:1568-76.

Gussekloo J, Schaap MC, Frölich M, et al. 2000. C-reactive protein is a strong but nonspecific risk factor of fatal stroke in elderly persons. Arterioscler Thromb Vasc Biol, 20:1047-51.

Haffner SM, Greenberg AS, Weston WM, et al. 2002. Effect of rosiglitazone treatment on nontraditional markers of cardiovascular disease in patients with type 2 diabetes mellitus. Circulation, 106:679-84.

Han KH, Hong KH, Park JH, et al. 2004. C-reactive protein promotes monocyte chemoattractant protein-1-mediated chemotaxis through upregulating $\mathrm{CC}$ chemokine receptor 2 expression in human monocytes. Circulation, 109:2566-71.

Hansson GK, Libby P, Schöenbeck U, et al. 2002. Innate and adaptive immunity in the pathogenesis of atherosclerosis. Circ Res, 91:281-91.

Hansson GK, Libby P. 2006. The immune response in atherosclerosis: a double-edged sword. Nat Rev Immunol, 6:508-19.

Ikonomidis I, Andreotti F, Economou E, et al. 1999. Increased proinflammatory cytokines in patients with chronic stable angina and their reduction by aspirin. Circulation, 100:793-8.

Ikuta T, Okubo H, Ishibashi H, et al. 1986. Human lymphocytes synthesize C-reactive protein. Inflammation, 10:223-32.

Inoue T, Kato T, Uchida T, et al. 2005. Local release of C-reactive protein from vulnerable plaque or coronary arterial wall injured by stenting. $J$ Am Coll Cardiol, 46:239-45.

Jakimiuk AJ, Bogusiewics M, Skorupski P, et al. 2007. Relationship between estrogen receptor-alpha polymorphism and serum levels of vascular cell adhesion molecule-1, intercellular adhesion molecule-1, C-reactive protein and homocysteine in postmenopausal women. Gynecol Endocrinol, 23: 584-9.

Jialal I, Devaraj S, Venugopal SK. 2004. C-reactive protein: risk marker or mediator in atherothrombosis? Hypertension, 44:6-11.

Jiang S, Xia D, Samols D. 2006. Expression of rabbit C-reactive protein in transgenic mice inhibits development of antigen-induced arthritis. Scand J Rheumatol, 35:351-5.

Johnson RC, Chapman SM, Dong ZM, et al. 1997. Absence of P-selectin dalays fatty streak formation in mice. J Clin Invest, 99:1037-43.

Kashyap ML, McGovern ME, Berra K, et al. 2002. Long-term safety and efficacy of a once-daily niacin/lovastatin formulation for patients with dyslipidemia. Am J Cardiol, 89:672-8.

Kathiresan S, Larson MG, Vasan RS, et al. 2006. Contribution of clinical correlates and $13 \mathrm{C}$-reactive protein gene polymorphisms to inteindividual variability in serum C-reactive protein level. Circulation, 113:1415-23.

Koenig W. 2005. Predicting risk and treatment benefit in atherosclerosis: the role of C-reactive protein. Int J Cardiol, 98:199-206.

Kolb-Bachofen V, Puchta-Teudt N, Egenhofer C. 1995. Expression of membrane-associated C-reactive protein by human monocytes: indications for a selectin-like activity participating in adhesion. Glycoconj $J, 12: 122-7$.

Kopp HP, Kopp CW, Festa A, et al. 2003. Impact of weight loss on inflammatory proteins and their association with the insulin resistance syndrome in morbidly obese patients. Arterioscler Thromb Vasc Biol, 23:1042-7.
Kovacs A, Green F, Hansson LO, et al. 2005. A novel common sinlge nucleotide polymorphism in the promoter region of the C-reactive protein gene associated with the plasma concentration of C-reactive protein. Atherosclerosis, 178:193-8.

Kuta AE, Baum LL. 1986. C-reactive protein is produced by a small number of normal human peripheral blood lymphocytes. J Exp Med, 164:321-6.

Lagrand WK, Visser CA, Hermens WT, et al. 1999. C-reactive protein as a cardiovascular risk factor: more than an epiphenomenon? Circulation, 100:96-102.

Lakka HM, Lakka TA, Rankinen T, et al. 2006. The TNF-alpha G-308A polymorphism is associated with C-reactive protein levels: the HERITAGE Family Study. Vascul Pharmacol, 44:377-83.

LaMonte MJ, Durstine JL, Yanowitz FG, et al. 2002. Cardiorespiratory fitness and C-reactive protein among a tri-ethnic sample of women. Circulation, 106:403-6.

Libby P, Ridker PM. 2004. Inflammation and atherosclerosis: role of C-reactive protein in risk assessment. Am J Med, 116(Suppl 6A):9S-16S.

Lincoff AM, Kereiakes DJ, Mascelli MA, et al. 2001. Abciximab suppresses the rise in levels of circulating inflammatory markers after percutaneous coronary revascularization. Circulation, 104:163-7.

Lipscombe LL, Gomes T, Lévesque LE, et al. 2007. Thiazolidinediones and cardiovascular outcomes in older patients with diabetes. JAMA, 298:2634-43.

Lowe GD, Yarnell JW, Rumley A, et al. 2001. C-reactive protein, fibrin Ddimer, and incident ischemic heart disease in the Speedwell study: are inflammation and fibrin turnover linked in pathogenesis? Arterioscler Thromb Vasc Biol, 21:603-10.

Mahmoud FA, Rivera NI. 2002. The role of C-reactive protein as a prognostic indicator in advanced cancer. Curr Oncol Rep, 4:250-5.

Mancia G, De Backer G, Dominiczak A, et al. 2007. 2007 Guidelines for the management of arterial hypertension: The Task Force for the Management of Arterial Hypertension of the European Society of Hypertension (ESH) and of the European Society of Cardiology (ESC). Eur Heart $J, 28: 1462-536$.

Melenovsky V, Malik J, Wichterle D, et al. 2002. Comparison of the effects of atorvastatin or fenofibrate on nonlipid biochemical risk factors and the LDL particle size in subjects with combined hyperlipidemia. $\mathrm{Am}$ Heart $J$, 144:E6.

Mendall MA, Strachan DP, Butland BK, et al. 2000. C-reactive protein: relation to total mortality, cardiovascular mortality and cardiovascular risk factors in men. Eur Heart J, 21:1584-90.

Miller DT, Zee RY, Suk Danik J, et al. 2005. Association of common CRP gene variants with CRP levels and cardiovascular events. Ann Hum Genet, 69:623-38.

Mori S, Nakata Y, Endo H. 1991. Involvements of fibronectin and lysophosphatidylcholine for selective binding of C-reactive protein. Cell Mol Biol, 37:421-31.

Mortensen RF, Zhong W. 2000. Regulation of phagocytic leukocyte activities by C-reactive protein. J Leukoc Biol, 67:495-500.

Nabata A, Kuroki M, Ueba H, et al. 2007. C-reactive protein induces endothelial cell apoptosis and matrix metalloproteinase-9 production in human mononuclear cells: implication for the destabilization of atherosclerotic plaque. Atherosclerosis, [Epub ahead of print].

Nerurkar SS, McDevitt PJ, Scott GF, et al. 2005. Lipopolysaccharide (LPS) contamination plays the real role in C-reactive protein-induced IL-6 secretion from human endothelial cells in vitro. Arterioscler Thromb Vasc Biol, 24:e136.

Nissen SE, Wolski K. 2007. Effect of rosiglitazone on the risk of myocardial infarction and death from cardiovascular causes. N Engl J Med, 356: $2457-71$.

Osawa H, Tabara Y, Kawamoto R, et al. 2007. Plasma resistin, associated with single nucleotide polymorphism -420 , is correlated with insulin resistance, lower HDL cholesterol, and high-sensitivity C-reactive protein in the Japanese general population. Diabetes Care, 30:1501-6.

Pai JK, Mukamal KJ, Rexrode KM, et al. 2008. C-reactive protein (CRP) gene polymorphisms, CRP levels, and risk of incident coronary heart disease in two nested Case-Control Study. PLoS ONE, 3:e1395. 
Park R, Detrano R, Xiang M, et al. 2002. Combined use of computed tomography coronary calcium scores and $\mathrm{C}$-reactive protein levels in predicting cardiovascular events in nondiabetic individuals. Circulation, 106:2073-7.

Pasceri V, Willerson JT, Yeh ET. 2000. Direct proinflammatory effect of C-reactive protein on human endothelial cells. Circulation, $102: 2165-8$

Paul A, Ko KW, Li L, et al. 2004. C-reactive protein accelerates the progression of atherosclerosis in apolipoprotein E-deficient mice. Circulation, 109:647-55.

Pearson TA, Mensah GA, Alexander RW, et al. 2003. Markers of inflammation and cardiovascular disease: application to clinical and public health practice: A statement for healthcare professionals from the Centers for Disease Control and Prevention and the American Heart Association. Circulation, 107:499-511.

Pepys MB, Hirschfield GM. 2003. C-reactive protein: a critical update. $J$ Clin Invest, 111:1805-12.

Pepys MB, Hawkins PN, Kahan MC, et al. 2005. Proinflammatory effects of bacterial recombinant human C-reactive protein are caused by contamination with bacterial products, not by $\mathrm{C}$-reactive protein itself. Circ Res, 97:e97-e103.

Pischon T, Hankinson SE, Hotamisligil GS, et al. 2003. Habitual dietary intake of n-3 and n-6 fatty acids in relation to inflammatory markers among US men and women. Circulation, 108:155-60.

Reuben DB, Judd-Hamilton L, Harris TB, et al. 2003. The associations between physical activity and inflammatory markers in high-functioning older persons: MacArthur Studies of Successful Aging. J Am Geriatr Soc, 51:1125-30.

Ridker PM, Cushman M, Stampfer MJ, et al. 1997. Inflammation, aspirin, and the risk of cardiovascular disease in apparently healthy men. N Engl J Med, 336:973-9.

Ridker PM, Buring JE, Shih J, et al. 1998. Prospective study of C-reactive protein and the risk of future cardiovascular events among apparently healthy women. Circulation, 98:731-3.

Ridker PM, Cushman M, Stampfer MJ, et al. 1998. Plasma concentration of C-reactive protein and risk of developing peripheral vascular disease. Circulation, 97:425-8.

Ridker PM, Rifai N, Pfeffer MA, et al. 1999. Long-term effects of pravastatin on plasma concentration of C-reactive protein. The Cholesterol and Recurrent Events (CARE) Investigators. Circulation, 100:230-5.

Ridker PM, Hennekens CH, Buring JE, et al. 2000. C-reactive protein and other markers of inflammation in the prediction of cardiovascular disease in women. $N$ Engl J Med, 342:836-43.

Ridker PM, Rifai N, Pfeffer M, et al. 2000. Elevation of tumor necrosis factor-alpha and increased risk of recurrent coronary events after myocardial infarction. Circulation, 101:2149-53.

Ridker PM, Rifai N, Clearfield M, et al. Air Force/Texas Coronary Atherosclerosis Prevention Study Investigators. 2001. Measurement of C-reactive protein for the targeting of statin therapy in the primary prevention of acute coronary events. N Engl J Med, 344:1959-65.

Ridker PM, Stampfer MJ, Rifai N. 2001. Novel risk factors for systemic atherosclerosis: a comparison of C-reactive protein, fibrinogen, homocysteine, lipoprotein(a), and standard cholesterol screening as predictors of peripheral arterial disease. JAMA, 285:2481-5.

Ridker PM, Rifai N, Rose L, et al. 2002. Comparison of C-reactive protein and low-density lipoprotein cholesterol levels in the prediction of first cardiovascular events. $N$ Engl J Med, 347:1557-65.

Ridker PM, Fonseca FA, Genest J, et al. 2007. Baseline characteristics of participants in the JUPITER trial, a randomized placebo-controlled primary prevention trial of statin therapy among individuals with low low-density lipoprotein cholesterol and elevated high-sensitivity C-reactive protein. Am J Cardiol, 100:1659-64.

Roivainen M, Viik-Kajander M, Palosuo T, et al. 2000. Infections, inflammation, and the risk of coronary heart disease. Circulation, 101:252-7.

Root M, Cobb F. 2004. Traditional risk factors for coronary heart disease. JAMA, 291:299.
Rowe IF, Soutar AK, Trayner IM, et al. 1984. Circulating human C-reactive protein binds very low density lipoproteins. Clin Exp Immunol, $58: 237-44$

Russell AI, Cunninghame Graham DS, Shepherd C, et al. 2004. Polymorphism at the $\mathrm{C}$-reactive protein locus influences gene expression and predisposes to systemic lupus erythematosus. Hum Mol Genet, 13:137-47.

Rydén L, Standl E, Bartnik M, et al. 2007. Guidelines on diabetes, prediabetes, and cardiovascular diseases: executive summary. The Task Forse on Diabetes and Cardiovascular Diseases of the European Society of Cardiology (ESC) and of the European Association for the Study of Diabetes (EASD). Eur Heart J, 28:88-136.

Shin KK, Jang Y, Koh SJ, et al. 2007. Influence of the IL-6 -572> G polymorphism on inflammatory markers according to cigarettes smoking in Korean healthy men. Cytokine, 39:116-22.

Singh P, Hoffmann M, Wolk R, et al. 2007. Leptin induces C-reactive protein expression in vascular endothelial cells. Arterioscler Thromb Vasc Biol, 27:e302-7.

Staels B, Koenig W, Habib A, et al. 1998. Activation of human aortic smooth-muscle cells is inhibited by PPARalpha but not by PPARgamma activators. Nature, 393:790-3.

Sun H, Koike T, Ichikawa T, et al. 2005. C-reactive protein in atherosclerotic lesions: its origin and pathophysiological significance. Am J Pathol, 167:1139-48.

Sykora J, Subrt I, Didek P, et al. 2006. Cytokine tumor necrosis factor-alpha A promoter gene polymorphism at position $-308 \mathrm{G} \mathrm{-->} \mathrm{A} \mathrm{and} \mathrm{pediat-}$ ric inflammatory bowel disease: implications in ulcerative colitis and Crohn's disease. J Pediatr Gastroenterol Nutr, 42:479-87.

Szalai AJ, McCrory MA, Cooper GS, et al. 2002. Association between baseline levels of C-reactive protein (CRP) and a dinucleotide repeat polymorphism in the intron of the CRP gene. Genes Immun, 3:14-19.

Szalai AJ, Wu J, Lange EM, et al. 2005. Single-nucleotide polymorphisms in the C-reactive protein (CRP) gene promoter that affect transcription factor binding, alter transcriptional activity, and associate with differences in baseline serum CRP level. J Mol Med, 83:440-7.

Tall AR. 2004. C-reactive protein reassessed. N Engl J Med, 350:1450-2.

Tang NP, Wang LS, Yang L, et al. 2007. A polymorphism in the resistin gene promoter is related to increased C-reactive protein levels in patients with coronary artery disease. Clin Chem Lab Med, 45:1471-5.

Taylor KE, Giddins JC, Van den Berg CW. 2005. C-reactive protein-induced in vitro endothelial cell activation is an artefact caused by azide and lipopolysaccharide. Arterioscler Thromb Vasc Biol, 25:1225-30.

Tchernof A, Nolan A, Sites CK, et al. 2002. Weight loss reduces C-reactive protein level in obese postmenopausal women. Circulation, 105:564-9.

Thompson D, Pepys MB, Wood SP. 1999. The physiological structure of human C-reactive protein and its complex with phosphocholine. Structure, 7:169-77.

Tillet WS, Francis T. 1930. Serological reactions in pneumonia with a non-protein somatic fraction of the Pneumococcus. J Exp Med, 52:561-71.

Torzewski M, Rist C, Mortensen RF, et al. 2000. C-reactive protein in the arterial intima: role of $\mathrm{C}$-reactive protein receptor-dependent monocyte recruitment in atherogenesis. Arterioscler Thromb Vasc Biol, 20:2094-9.

Van den Berg CW, Taylor KE, Lang D. 2004. C-reactive protein-induced in vitro vasorelaxation is an artefact caused by the presenc e of sodium azide in commercial preparations. Arterioscler Thromb Vasc Biol, 24: e168-71.

Van der Vusse GJ, van Bilsen M, Reneman RS. 1994. Ischemia and reperfusion induces alterations in membrane phospholipids: an overview. Ann N Y Acad Sci, 723:1-14.

Vasan RS, Sullivan LM, Roubenoff R, et al. 2003. Inflammatory markers and risk of heart failure in elderly subjects without prior myocardial infarction: the Framingham Heart Study. Circulation, 107:1486-91.

Venugopal SK, Devaraj S, Yuhanna I, et al. 2002. Demostration that C-reactive protein decreases eNOS expression and bioactivity in human aortic endothelial cells. Circulation, 106:1439-41. 
Venugopal SK, Devaraj S, Jialal I. 2003. C-reactive protein decreases prostacyclin release from from human aortic endothelial cells. Circulation, 108:1676-8

Verma S, Li SH, Badiwala MV, Weisel RD, et al. 2002. Endothelin antagonism and interleukin- 6 inhibition attenuate the proatherogenic effects of C-reactive protein. Circulation, 105:1890-6.

Verma S, Wang CH, Li Sh, et al. 2002. A self-fulfilling prophecy: C-reactive protein attenuates nitric oxide production and inhibits angiogenesis. Circulation, 106:913-19.

Vermeire S, Van Assche G, Rutgeerts P. 2004. C-reactive protein as a marker for inflammatory bowel disease. Inflamm Bowel Dis, 10:661-5.

Walston JD, Fallin MD, Cushman M, et al. 2007. Il-6 gene variation is associated with IL- 6 and C-reactive protein levels but not cardiovascular outcomes in the Cardiovascular Healthy Study. Hum Genet, 122:485-94.

Wang CH, Li SH, Weisel RD, et al. 2003. C-reactive protein upregulates angiotensin type 1 receptors in vascular smooth muscle. Circulation, 107:1783-90.

Wannamethee SG, Lowe GD, Whincup PH, et al. 2002. Physical activity and hemostaic and inflammatory variables in elderly men. Circulation, 105:1785-90.

Williams TN, Zhang CX, Game BA, et al. 2004. C-reactive protein stimulates MMP-1 expression in U937 histiocytes through Fc[gamma]RII and extracellular signal-regulated kinase pathways: an implication of CRP involvement in plaque destabilization. Arterioscler Thromb Vasc Biol, 24:61-6.
Wong LY, Leung RY, Ong KL, Cheung BM. 2007. Plasma levels of fibrinogen and C-reactive protein are regulated to interleukin-6 gene $-572 \mathrm{C}>\mathrm{G}$ polymorphism in subjects with and without hypertension. J Hum Hypertens, 21:875-82.

Woollard KJ, Phillips DC, Griffiths HR. 2002. Direct modulatory effect of C-reactive protein on primary human monocytes adhesion to human endothelial cells. Clin Exp Immunol, 130:256-62.

Worthley SG, Osende JI, Helft G, et al. 2001. Coronary artery disease: pathogenesis and acute coronary syndromes. Mt Sinai J Med, 68:167-81.

Xia D, Samols D. 1997. Transgenic mice expressing rabbit C-reactive protein are resistant to endotoxiemia. Proc Natl Acad Sci U.S.A., 94:2575-80

Zhang R, Becnel L, Li M, et al. 2006. C-reactive protein impairs human CD14+ monocyte-derived dendritic cell differentiation, maturation and function. Eur J Immunol, 36:2993-3006.

Zhang D, Che D, Zhao S, Sun Y. 2007. Effects of atorvastatin on C-reactive protein secretions by adipocytes in hypercholesterolemic rabbits. $J$ Cardiovasc Pharmacol, 50:281-5.

Zhang YY, Gottardo L, Mlynarski W, et al. 2007. Genetic variability at the leptin receptor (LEPR) locus is a determinant of plasma fibrinogen and C-reactive protein levels. Atherosclerosis, 191:121-7.

Zhong W, Zen Q, Tebo J, et al. 1998. Effect of human C-reactive protein on chemokine and chemotactic factor-induced neutrophil chemotaxis and signaling. J Immunol, 161:2533-40. 
